\title{
Rancang Bangun Media Informasi Interaktif Berbasis Desktop sebagai media informasi Program Studi STMIK STIKOM Indonesia
}

\author{
I Nyoman Agus Suarya P.M.Sn ${ }^{1}$, I Made Marthana Yusa.S.Ds, M.Des ${ }^{2}$ \\ STMIK STIKOM Indonesia \\ 1'nyoebaliphotography@gmail.com, ${ }^{2}$ made.marthana@gmail.com
}

\begin{abstract}
ABSTRAK. STIKI Indonesia adalah salah satu kampus favorit yang berada di pulau Bali yang mengajarkan tentang aplikasi dari beberapa bidang ilmu yang berbasis komputer. STIKI Indonesia bernaung di bawah KOPERTIS wilayah VIII yang memiliki tujuan menciptakan generasi muda yang kreatif, cerdas dan bermanfaat. Program Studi (Prodi) Teknik Informatika (TI) dan Program Studi (Prodi) Sistem Komputer (SK) adalah dua Program Studi yang dimiliki STMIK STIKOM Indonesia (STIKI Indonesia), yang tersedia untuk calon mahasiswa yang berasal dari SMA, SMK dan Sekolah sederajat di Indonesia. Namun, yang terjadi selama ini adalah adanya kesenjangan sumber informasi tentang program studi sehingga terjadi pergeseran pemahaman pada masyarakat, khususnya pada kurikulum yang ditawarkan dan lingkungan belajar kampus.

Dari hasil pengamatan secara langsung didapatkan sebuah temuan yaitu kurangnya pengetahuan marketingship para pelaku kegiatan marketing STIKI Indonesia mengenai kehidupan kampus, terutama informasi terkait program studi. Hal ini mengakibatkan kurangnya pengetahuan calon mahasiswa tentang kegiatan yang dilaksanakan oleh Prodi di lingkungan kampus STIKI Indonesia. Sebagian besar calon mahasiswa memiliki kecenderungan memilih datang ke kampus STIKI Indonesia untuk mengetahui secara langsung profil Prodi TI dan SK dibanding hanya mengetahui melalui media informasi dan promosinya. Sayangnya, karyawan yang berinteraksi langsung dengan calon mahasiswa-yang bekerja di bagian front office-memiliki pengetahuan yang beragam, dikarenakan pengalaman yang berbeda, sehingga terjadi degradasi informasi. Informasi yang disampaikan ke calon mahasiswa pun berbeda. Antara bagian front office dengan bagian marketing juga memiliki ketidaksesuaian informasi terkait tentang Prodi secara spesifik. Hal tersebut dapat menyebabkan tidak tersampaikannya satu konsep yang jelas tentang berbagai informasi terkait program studi. Perlu adanya suatu media yang menjembatani keseragaman konsep penyampaian informasi oleh marketing dan front office.

Multimedia Interaktif berbasis desktop yang ditempatkan di bagian Front Office merupakan salah satu solusi yang dapat diwujudkan. Multimedia interaktif ini dapat menyertakan media audio visual yang bersifat interaktif sehingga informasi dapat disampaikan secara langsung kepada responden. Dengan bantuan multimedia interaktif ini pihak front office tidak akan kesulitan untuk mensosialisasikan informasi kampus dalam kondisi dimana calon mahasiswa datang ke kampus dalam jumlah yang terlalu banyak, sehingga sulit ditangani dengan baik. Dari uraian di atas maka penelitian tentang produk multimedia interaktif dapat dilaksanakan sehingga dalam penelitian ini penulis mengambil judul "Rancang Bangun Media Informasi Interaktif Berbasis Desktop Sebagai Media Informasi Program Studi STMIK STIKOM Indonesia".
\end{abstract}

Kata Kunci : Media Informasi, Teknik Informatika, Sistem Komputer, STIKI Indonesia

\section{PENDAHULUAN}

\subsection{Latar Belakang}

Program Studi (Prodi) Teknik Informatika dan Program Studi (Prodi) Sistem Komputer adalah dua Program Studi yang dimiliki STMIK STIKOM Indonesia (STIKI Indonesia), yang tersedia untuk calon mahasiswa yang berasal dari SMA, SMK dan Sekolah sederajat di Indonesia. STIKI Indonesia adalah salah satu kampus favorit yang berada di pulau Bali yang mengajarkan tentang aplikasi dari beberapa bidang ilmu yang berbasis komputer.STIKI Indonesia bernaung di bawah KOPERTIS wilayah VIII yang memiliki tujuan menciptakan generasi muda yang kreatif, cerdas dan bermanfaat. Namun, yang terjadi selama ini adalah adanya kesenjangan sumber informasi tentang program studi sehingga terjadi pergeseran pemahaman pada masyarakat, khususnya pada kurikulum yang ditawarkan dan lingkungan belajar kampus.

Temuan yang diperoleh dari hasil pengamatan secara langsung yaitu kurangnya pengetahuan marketing tentang kehidupan kampus terutama informasi terkait program studi. Hal ini mengakibatkan kurangnya pengetahuan calon mahasiswa terkait berbagai kegiatan yang dilaksanakan oleh Prodi di lingkungan kampus STMIK STIKOM Indonesia. Tidak sebandingnya jumlah antara calon mahasiswa yang datang ke kampus dengan petugas Front Office yang melayani mahasiswa juga menyebabkan beragamnya informasi yang diperoleh. Petugas Front Office yang memiliki tingkat regenerasi tinggi-sering mengalami perubahan formasi, kecenderungannya memberikan informasi tentang program studi hanya melalui media brosur. Karyawan yang bekerja di bagian Front Office memiliki pengetahuan yang berbeda dikarenakan pengalaman yang berbeda, sehingga tranformasi komunikasi ke calon mahasiswa pun berbeda. Antara bagian Front Office dengan bagian 
marketing juga memiliki ketidaksesuaian informasi terkait tentang program studi secara spesifik, sehingga dapat menyebabkan tidak terciptanya satu konsep yang jelas tentang informasi informasi yang terkait program studi.

Dari pengamatan yang telah dilakukan terhadap kesesuaian informasi yang terkait program studi di STMIK STIKOM Indonesia ternyata membawa pengaruh negatif terhadap calon mahasiswa yang sudah menjadi mahasiswa. Mahasiswa pada akhirnya berganti program studi. Berdasar hasil diskusi dengan pihak Prodi, beberapa mahasiswa merasa tidak nyaman dalam mengikuti perkuliahan. Mahasiswa pada akhirnya merasa dirugikan disebabkan informasi yang tidak sesuai saat sosialisasi dengan saat mereka sudah menjadi mahasiswa. Dari hasil wawancara didapatkan bahwa Kepala Program Studi Teknik informatika, I Putu Gede Budayasa,SST.Par,M.T.I menyampaikan adanya kesenjangan informasi antara pihak marketing dengan pihak Prodi menyebabkan banyaknya mahasiswa kebingungan dalam menjalankan perkuliahan. Pejabat Pembantu Ketua 1, Aniek Suryanti Kusuma, M.Kom tidak menampik permasalahan ini. Aniek menyampaikan perlu adanya media secara khusus yang dapat dijadikan media informasi yang tepat sehingga segala bentuk permasalahan yang ada dalam kegiatan program studi dapat diketahui oleh mahasiswa sepenuhnya.

STMIK STIKOM Indonesia adalah kampus IT yang berbasis komputer. STMIK STIKOM Indonesia harus dapat memperkuat citra IT di kalangan mahasiswa. Selama ini media promosi yang dimiliki masih berpedoman pada media brosur dan presentasi dari pihak marketing. Media informasi yang berbasis pada interaktif hanya ada pada website. Presentasi oleh pihak marketing memanfaatkan slide yang bersifat audio visual namun karena keterbasan waktu pada akhirnya interakaksi secara personal menjadi sangat terbatas, sehingga informasi tidak utuh disampaikan. Ketika calon mahasiswa berkeinginan mengetahui dan mendapatkan informasi tentang kampus, penyampaian informasi juga akan menjadi berbeda. Media website yang dipergunakan selama ini hanya menyediakan informasi kampus secara umum. Kenyamanan mengakses informasi di web sangat dipengaruhi oleh kualitas akses. Dari uraian tersebut tentunya STMIK STIKOM Indonesia harus mengkaji kembali media promosinya. STMIK STIKOM Indonesia membutuhkan sebuah media komunikasi visual yang mampu menyampaikan informasi dengan akurat.

Multimedia Interaktif berbasis desktop merupakan salah satu solusi yang dapat diwujudkan. Media ini dapat menyertakan penyampaian pesan dalam wujud audio visual yang bersifat interaktif sehingga informasi dapat disampaikan secara langsung kepada responden dengan kandungan informasi yang lebih lengkap dan padat. Dalam multimedia interaktif, responden dapat mengetahui satu bentuk informasi yang sama. Dengan format audio visual serta animasi, media diharapkan bisa memberikan kenyamanan dalam mengakses informasi. Multimedia interaktif berbasis desktop akan lebih mendukung citra Sekolah Tinggi berbasis komputer yang hightech jika nantinya dapat disampaikan melalui monitor layar sentuh. Dengan solusi ini, pihak front office tidak akan kesulitan untuk mensosialisasikan informasi kampus dengan kondsi pengunjung yang padat. Dari uraian di atas maka penelitian tentang produk multimedia interaktif dapat dilaksanakan sehingga dalam penelitian ini penulis mengambil judul "Rancang Bangun Media Informasi Interaktif Berbasis Dekstop Sebagai Media Informasi Program Studi STMIK STIKOM Indonesia".

\subsection{Rumusan Masalah}

Uraian di atas menyampaikan sangat pentingnya sebuah media informasi yang tepat yang dapat menyampaikan informasi penting terkait program studi di STMIK STIKOM Indonesia. Rumusan maslah dalam penelitian ini adalah : "Bagaimana merancang dan membangun sebuah media informasi interaktif berbasis desktop sebagai media informasi program studi di STMIK STIKOM Indonesia?"

\subsection{Tujuan Penelitian}

Memberikan alternatif media promosi bagi STMIK STIKOM Indonesia dalam menginformasikan program studi yang sesuai dengan realita kehidupan kampus berbasis desktop.

\section{METODE PENELITIAN}

\subsection{Lingkungan Penelitian}

\subsubsection{Tempat danWaktu Penelitian}

Penelitian ini dilaksanakan di Kampus STMIK STIKOM Indonesia yang beralamat di Jalan Tukad Pakerisan No. 97 Denpasar Bali. Sedangkan waktu penelitian ini adalah selama 4 bulan.

\subsubsection{Populasi dan Sampel}

Populasi dalam penelitian ini adalah seluruh pemangku kepentingan tata kelola STMIK STIKOM Indonesia. Sedangkan sampel yang digunakan dalam penelitian ini beberapa dosen, mahasiswa dan kepala divisi yang terkait dengan sistem akademik STMIK STIKOM Indonesia.

\subsection{Metode Pengumpulan Data \\ 2.2.1Pengumpulan Data Primer \\ 1. Observasi}

Observasi dilakukan di lingkungan STMIK STIKOM Indonesia, terutama proses penerimaan mahasiswa baru. Observasi telah dilaksanakan mulai semester Ganjil 2014. Dari hasil observasi juga diperoleh data tentang sistem penyampaian informasi program studi ditujukan untuk calon mahasiswa STMIK STIKOM Indonesia dalam melakukan proses pengerjaan tugas akhir. Penanggung jawab untuk penyusunan dan 
pelaksanaan prosedur ini adalah Kepala Program Studi STMIK STIKOM Indonesia. Penyimpanan bukti-bukti pelaksanaan prosedur ini menjadi tanggung jawab Sekretaris Program Studi STMIK STIKOM Indonesia.

2. Wawancara

Wawancara ini dilakukan dengan bertanya langsung pada orang yang dianggap dapat memberikan informasi secara mendetail dan sebenarnya. Wawancara dilakukan dengan Pembantu Ketua 1, Kepala Program Studi Teknik Komputer dan Kepala Program Studi Sistem Komputer, Dosen Pengampu mata kuliah dan Calon mahasiswa serta mahasiswa STMIK STIKOM Indonesia.

Yang pertama wawancara dilakukan bertahap terhadap Bapak Robert Wijaya, S.Kom selaku marketing STMIK STIKOM indonesia pada hari Selasa, 12 April 2016. Wawancara dilakukan untuk mengetahui informasi apa saja yang di sampaikan saat melakukan visitasi ke sekolah-sekolah. Kemudian kendala yang pernah di alami pada saat melakukan visitasi.

Penulis juga melakukan wawancara dengan staff front office STMIK STIKOM Indonesia yaitu Ida Ayu Ratih Yuliandari dan Anik Suryantini. Wawancara ini dilakukan untuk mendapatkan informasi tentang hal yang disampaikan oleh staff front office saat calon mahasiswa baru mencari informasi. Kemudian kendala yang dihadapi oleh staff front office.

Dilanjutkan dengan wawancara Pada hari Sabtu 16 April 2016, kepada Kaprodi Teknik Informatika Bapak I Putu Gede Budayasa, Sst.Par., M.T.I, Bapak I Nyoman Buda Hartawan, M.Kom selaku Kaprodi Sistem Komputer, dan Ibu Aniek Suryanti Kusuma, M.Kom selaku Pembantu Ketua 1. Dalam Wawancara ini bertujuan untuk mencari informasi tentang kendala mahasiswa sehingga pindah jurusan. Serta menanyakan saran maupun pendapat untuk hal-hal apa saja yang harus ditambahkan dalam penelitian ini.

Pada tanggal 19 April 2016 hingga 2 Mei 2016, penulis juga melakukan wawancara kepada 8 orang mahasiswa yang pindah program studi maupun konsentrasi. Wawancara ini dilakukan bertujuan untuk mencari informasi tentang penyebab mereka pindah program studi maupun konsentrasi. Kemudian informasi apa saja yang mereka ketahui tentang program studi yang ada pada STMIK STIKOM Indonesia, dan informasi apa saja yang mereka dapatkan dari brosur, saat sosialisasi, dan front office.

1.Metode Kuesioner

Penggunaan kuisioner dalam penelitian ini bertujuan untuk mengetahui pendapat maupun saran mahasiswa tentang informasi program studi yang terdapat pada STMIK STIKOM Indonesia. Penyebaran kuesioner dibagikan kepada 50 orang mahasiswa STMIK STIKOM Indonesia semester 2 hingga semester 6. Dengan menggunakan metode kuisioner ini untuk mengetahui seberapa tahukah mereka tentang program studi STMIK STIKOM Indonesia dan media apa yang dibutuhkan untuk menampilkan informasi program studi yang lebih detail dan efektif.

\subsubsection{Data Sekunder}

1. Kepustakaan

Metode ini digunakan untuk mendapatkan data yang bersifat teoritis dari beberapa literatur atau bahan bacaan yang dapat dipertanggungjawabkan kebenarannya (Surakhmad, 1787 : 2), misalnya mencari informasi data-data pada buku, artikel, majalah, surat kabar, brosur dan media lainnya yang ada hubunganya dengan teknik membuat film.

Metode studi pustaka yang merupakan teknik pengumpulan data yang bersifat teoritis yang diperoleh dengan melakukan studi pustaka atau membaca buku-buku dan literatur yang ada hubungannya dengan permasalahan yang dibahas. Teori yang digunakan dalam perancangan ini adalah teori mengenai multimedia interaktif. Mulai dari proses perancangan hingga hasil akhir berupa media informasi interaktif yang dijadikan acuan dalam perancangaan media informasi interaktif tentang program studi di STMIK STIKOM Indonesia berbasis desktop. Selain itu penulis juga mengumpulkan informasi dari beberapa penelitian terdahulu yang membahas tentang media informasi interaktif prosedur akademik dan pengenalan UKM di STMIK STIKOM Indonesia.

2.Dokumentasi

Yaitu metode dengan pengambilan gambar-gambar berupa foto atau sketsa obyek. Dalam hal ini peneliti melakukan pengambilan gambar-gambar berupa foto atau sketsa obyek di STMIK STIKOM Indonesia untuk menambah data laporan.

\subsection{Metode Analisa Data}

\subsubsection{Penjabaran Hasil Pengumpulan Data}

Dari beberapa metode pengumpulan data yang telah penulis lakukan, didapatkan data-data berupa dokumentasi hasil wawancara, data hasil observasi, data hasil dari metode dokumentasi dan data hasil dari studi pustaka. Adapun penjabaran hasil pengumpulan data adalah sebagai berikut.

1. Data Hasil Observasi

Data hasil observasi yang dilakukan penulis pada media informasi brosur dan website bahwa media tersebut hanya menjabarkan informasi secara umum tentang program studi dan kurang mendetail. Kemudian pada form pendaftaran terdapat pilihan jurusan Sistem Komputer, TI-Manajemen Informatika, TI-Desain Grafis \& 
Multimedia, TI-Komputer \& Akuntansi Bisnis. Sehingga tidak adanya pemisahan antara program studi Teknik Informatika maupun Sistem Komputer.

2. Data Hasil Kuesioner

Data hasil kuesioner yang dibagikan kepada 50 orang mahasiswa STMIK STIKOM Indonesia, telah didapatkan hasil kuesioner sebanyak 96\% mahasiswa mengetahui apa itu program studi. Namun sebanyak $76 \%$ mahasiswa tidak mengetahui informasi program studi secara lebih detail. Mahasiswa yang menyatakan bahwa program studi tidak disampaikan secara detail saat mendaftar sebanyak 62\%. Dari hasil kuisioner didapatkan data bahwa 54\% mahasiswa kesulitan dalam mencari informasi program studi yang lebih detail. Sebanyak 54\% mahasiswa mengetahui multimedia interaktif dan 80\% mahasiswa setuju dengan media interaktif sebagai media penyampaian informasi program studi secara lebih lebih detail dan efektif.

Maka dapat disimpulkan bahwa, masih banyaknya mahasiswa yang kurang mengetahui informasi tentang program studi secara detail. Karena informasi program studi kurang tersampaikan secara detail saat melakukan pendaftaran. Dengan adanya media informasi interaktif diharapkan dapat dengan mudah mencari informasi program studi secara detail.

3. Data Hasil Wawancara

Wawancara yang dilakukan dengan Bapak Robert Wijaya, S.Kom selaku staff marketing STMIK STIKOM Indonesia. Telah didapatkan informasi bahwa, informasi yang disampaikan saat visitasi ke sekolah-sekolah adalah menjelaskan secara umum tentang kampus STMIK STIKOM Indonesia antara lain, fasilitas, jurusan, rincian biaya, syarat administrasi, dan lain-lain. Informasi tentang program studi secara detail tidak disampaikan karena adanya kendala keterbatasan waktu saat melakukan visitasi.

Data hasil wawancara yang dilakukan dengan Ida Ayu Ratih Yuliandari dan Anik Suryantini selaku staff front office, telah didapatkan informasi bahwa pihaknya hanya menjelaskan informasi secara umum sesuai yang ada dibrosur dan lebih terfokus ke fasilitas, rincian biaya, dan syarat administrasi. Informasi tentang program studi Teknik Informatika maupun Sistem Komputer secara detail hanya akan dijelaskan jika ada calon mahasiswa baru yang bertanya. Hal itu pun menjadi kendala dikarenakan tidak semua staff front office yang mempunyai basic jurusan IT.

Hasil wawancara yang dilakukan dengan Ibu Aniek Suryanti, M.Kom selaku Pembantu Ketua 1 STMIK STIKOM Indonesia, telah didapatkan informasi bahwa terkadang mahasiswa keliru dalam membedakan apa yang dimaksud program studi dengan konsentrasi atau peminatan. Beliau juga mengungkapkan bahwa ada mahasiswa yang pindah program studi maupun peminatan dikarenakan kurang paham tentang program studi atau peminatan yang dipilihnya. Ibu Aniek Suryanti juga menyarankan hal-hal yang perlu ditambahkan dalam media informasi tentang program studi untuk kedepannya antara lain apa saja yang dipelajari, peluang kerja kedepannya, serta produk hasil dari masing-masing program studi tersebut.

Hasil wawancara yang dilakukan dengan Bapak I Putu Gede Budayasa, Sst.Par., M.T.I selaku Kaprodi Teknik Informatika, didapatkan informasi bahwa mahasiswa kurang paham tentang informasi program studi. Beliau juga mengungkapkan bahwa ada mahasiswa yang pindah program studi dikarenakan tidak kuat dengan materinya serta kurang paham tentang informasi dari masing-masing program studi. Bapak I Putu Gede Budayasa juga mengatakan bahwa bisa saja pihak marketing tidak detail dalam menyampaikan informasi program studi. Hal yang perlu ditambahkan untuk media informasi tentang program studi kedepannya antara lain profil lulusan, serta peluang kerjanya.

Data hasil wawancara yang dilakukan dengan Bapak I Nyoman Buda Hartawan, M.Kom selaku Kaprodi Sistem Komputer, telah didapatkan informasi bahwa ada mahasiswa yang pindah program studi dikarenakan tidak cocok dengan yang dipilihnya. Beliau mengungkapkan hal itu terjadi dikarenakan informasi yang diterima mahasiswa tentang program studi hanya secara umum, sehingga ketika perkuliahan dimulai barulah mahasiswa tersebut merasa tidak cocok dengan program studi yang dipilihnya. Bapak I Nyoman Buda Hartawan menyarankan hal-hal yang perlu ditambahkan dalam media informasi tentang program studi kedepannya berisi tentang visi dan misi program studi, kompetensi keahlian, dan peluang kerja nantinya.

Hasil wawancara dari mahasiswa atas nama Jonathan Perdana Putra Kedoh, didapatkan informasi bahwa pada awalnya memilih jurusan TI-KAB dan memutuskan pindah ke TI-DGM karena setelah berjalan perkuliahan desain multimedia lebih menarik dan dibutuhkan untuk saat ini. Jonathan juga mengungkapkan bahwa tidak adanya informasi yang jelas pada setiap jurusan yang ada. Jonathan juga mengatakan informasi tentang program studi hanya dijelaskan gambaran umumnya saja.

Hasil wawancara dari mahasiswa atas nama Rieska Khoirunnisa, didapatkan informasi bahwa awalnya memilih jurusan TI-DGM dan memutuskan pindah ke TI-MTI. Karena pada awalnya informasi yang didapatkan bahwa desain multimedia hanya mempelajari membuat desain, edit foto dan film, namun setelah perkuliahan desain multimedia juga mengharuskannya untuk menggambar manual, sehingga Rieska tidak sanggup untuk melanjutkan dijurusan TI-DGM. Rieska juga mengatakan bahwa informasi tentang program studi yang disampaikan oleh pihak kampus masih umum-umumnya saja.

4. Metode Dokumentasi 
Dari hasil penelitian melalui metode dokumentasi, penulis mendapatkan data tentang mahasiswa yang pindah program studi maupun peminatan, serta foto form pendaftaran dan foto brosur STMIK STIKOM Indonesia yang menampilkan informasi program studi secara umum. Penulis juga memiliki file rekaman dan dokumentasi saat wawancara.

5. Metode Studi Pustaka

Dari hasil penelitian melalui metode studi pustaka didapatkan informasi tentang kelebihan interaktif multimedia sebagai media informasi. Hasil dari metode penelitian studi pustaka telah dipaparkan pada bab II, pada sub bab 2.1 yang membahas tentang tinjauan penelitian terdahulu.

\subsubsection{Analisis Data Penelitian}

Setelah melakukan analisa terhadap data yang telah didapatkan melalui metode-metode pengumpulan data, maka dapat disimpulkan bahwa kendala yang dihadapi adalah informasi tentang program studi hanya dijelaskan secara umum saja dan belum bisa tersampaikan secara detail. Karena kurangna waktu saat marketing melakukan visitasi ke sekolah-sekolah dan staff front office juga hanya terfokus dalam penyampaian fasilitas, syarat administrasi, dan rincian biaya. Front office juga mengalami kendala ketika ada calon mahasiswa baru yang bertanya lebih detail tentang program studi dikarenakan tidak semua staff front office yang mempunyai basic jurusan IT. Informasi yang ada pada brosur hanya menjelaskan pengertian tentang program studi secara umum, hal tersebut mengakibatkan adanya mahasiswa yang pindah program studi maupun konsentrasi saat sudah menjalani proses perkuliahan karena merasa tidak cocok, serta masih kelirunya para mahasiswa dalam membedakan apa yang dimaksud antara program studi dan konsentrasi. Padahal informasi tentang program studi sangat penting agar calon mahasiswa baru tidak salah dalam menentukan pilihan sesuai minat dan kemampuannya masing-masing.

Dari permasalahan di atas, maka dapat disimpulkan bahwa dibutuhkannya suatu media informasi alternatif yang mampu menjelaskan informasi program studi secara detail dan efektif. Pada media informasi alternatif akan ditambahkan informasi pendukung seperti produk hasil dari masing-masing program studi, profil lulusan dan peluang kerja nantinya. Perancangan media informasi interaktif sebagai media untuk menunjang informasi program studi Teknik Informatika dan Sistem Komputer pada STMIK STIKOM Indonesia. Media informasi interaktif dirasa mampu menjadi solusi dari permasalahan tersebut, karena berdasarkan data yang didapat dari hasil kuesioner dan wawancara yang dilakukan penulis. Serta media informasi interaktif mampu menampilkan teks, grafik, animasi, audio, gambar, dan video untuk mempermudah dalam penyampaian informasi.

\subsection{Skema Pola Perancangan}

Skema pola perancangan merupakan langkah-langkah pemikiran di dalam pembuatan media informasi interaktif guna memastikan pesan yang ingin disampaikan sesuai dengan sasaran. Skema pola perancangan dapat dilihat pada gambar 1. Latar belakang masalah dalam penelitian ini adalah informasi tentang program studi yang tidak secara detail disampaikan oleh pihak marketing pada saat melakukan visitasi ke sekolah-sekolah dikarenakan keterbatasan waktu. Kemudian pihak front office juga hanya menyampaikan informasi yang lebih terfokus ke fasilitas, sistem perkuliahan, serta rincian biaya kuliah kepada calon mahasiswa baru. Informasi tentang program studi secara detail hanya disampaikan jika ada siswa SMA/SMK yang bertanya, namun front office juga mengalami kendala ketika ada siswa SMA/SMK yang bertanya lebih detail tentang program studi Teknik Informatika maupun Sistem Komputer, dikarenakan tidak semua staff front office yang mempunyai basic jurusan $I T$.

Setelah mengetahui latar belakang masalah maka selanjutnya peneliti menentukan judul, yaitu "Perancangan Media Informasi Interaktif Tentang Program Studi Di STMIK STIKOM Indonesia berbasis desktop". Dari penjelasan di atas dapat dirumuskan permasalahan yang dihadapi penulis adalah bagaimana merancang media informasi interaktif tentang program studi di STMIK STIKOM Indonesia berbasis desktop. Adapun sasaran dari perancangan media informasi interaktif ini adalah siswa SMA/SMK yang akan melanjutkan kuliah di STMIK STIKOM Indonesia.

Setelah mengetahui tujuan dan sasaran dari penelitian, dijelaskan bahwa langkah selanjutnya adalah dilakukan pengumpulan data sebagai bahan atau landasan teori dari judul yang ditentukan. Kemudian dilakukan proses analisis data untuk menentukan konsep perancangan media informasi interaktif yang akan dibuat dengan menyatukan unsur-unsur visual. Kemudian melakukan perwujudan media informasi interaktif. Setelah media informasi interaktif dibuat, akan dilakukan suatu pengujian dengan metode kuisioner terhadap kaprodi teknik informatika, kaprodi sistem komputer dan beberapa dosen untuk memastikan media informasi interaktif dapat memeberikan informasi tentang program studi sesuai yang diharapkan. 


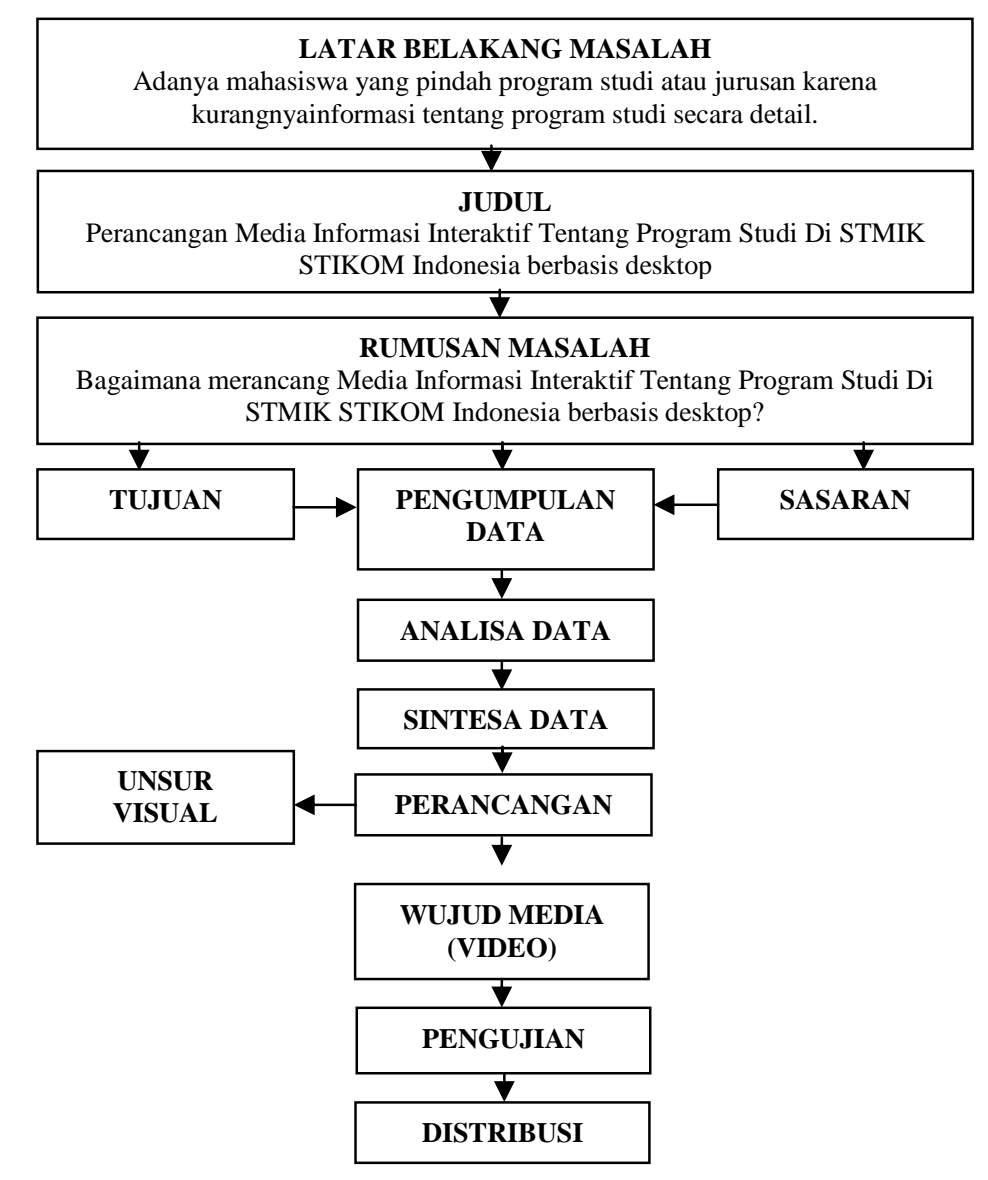

\subsection{Konsep Perancangan}

Gambar 1. Skema Pola Perancangan

Tema desain yang dipilih dalam pembuatan media informasi interaktif ini adalah (1)"vibrant warnawarni" yang pada implementasinya dapat dilihat dengan adanya banyak warna; dan (2) "informatif" yang pada implementasinya menyampaikan informasi yang padat. Yang dimaksud konsep "vibrant" adalah : media informasi ini dibuat dengan perpaduan warna-warna cerah. Hal ini bertujuan untuk menarik minat calon pengguna, dan mencegah pengguna agar tidak mengalami kebosanan saat mengakses informasi. Penggunaan warna cerah juga tetap dijaga agar tidak mengurangi tingkat keterbacaan teks. Konsep informatif membuat aplikasi ini padat dengan informasi. Diharapkan nantinya media informasi tetang program studi teknik informatika dan program studi sistem komputer ini bisa memberikan informasi yang mudah dipahami dan mudah diingat oleh user.

\subsubsection{Strategi Kreatif}

Strategi kreatif bertujuan untuk memaksimalkan suatu daya tarik visual melalui bentuk isi dan perwujudan media. Adapun strategi kreatif yang dirancang dalam multimedia interaktif sebagai media pembelajaran ini adalah sebagai berikut.

\section{Isi Pesan}

Isi pesan dalam media informasi interaktif ini adalah informasi tentang program studi teknik informatika dan sistem komputer, diantaranya pengertian visi dan misi tentang program studi, pembagian program studi, karya yang dihasilkan setiap program studi, dan sasaran kerja stiap program studi. Dengan adanya media informasi interaktif diharapkan dapat mempermudah dalam mencari informasi tentang program studi. Selain itu, pesan yang ingin disampaikan untuk calon mahasiswa baru yang ingin mencari informasi adalah mencari informasi itu mudah cepat dan efisien ditunjang dengan media informasi interaktif. 
2. Bentuk Pesan

Bentuk pesan dalam media informasi interaktif ini adalah berupa informasi tentang program studi yang dibuat lebih menarik dengan adanya animasi, suara, teks, gambar, video.

\subsubsection{Strategi Audio Visual}

1. Grafik

Strategi audio visual yang akan digunakan oleh penulis adalah sebagai berikut.

Dalam perancangan media informasi ini akan menggunakan gambar vector dan gambar bitmap. Gambar vector tersebut digunakan untuk desain layout, logo, dan tombol pada menu-menu dalam aplikasi. Sedangkan gambar bitmap yaitu seperti foto dokumentasi yang nantinya akan berada pada menu tertentu seperti Gambar 2 ilustrasi layout.

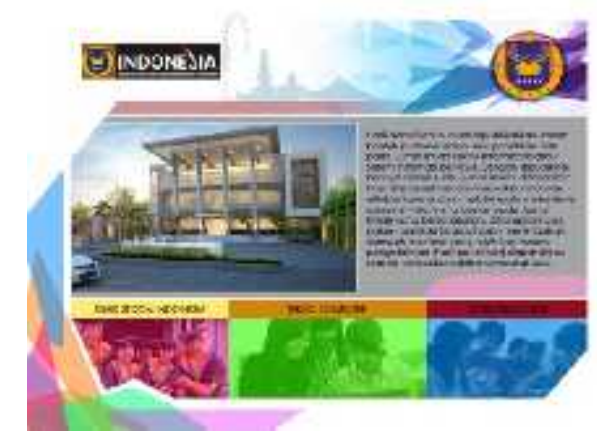

Gambar 2. Ilustrasi Layout

2. Huruf

Huruf yang digunakan adalah jenis font yang mudah dibaca, jelas, dan Menurut Supriyono $(2010,23)$ Dalam memilih huruf, nilai keterbacaan jauh lebih penting daripada keindahan. Bagaimanapun keindahan sebuah huruf, jika sulit dibaca maka bukan huruf yang baik. Maka font yang akan digunakan dalam perancangan media informasi ini adalah Arial, Brady Bunch, Bebas Neue, Century dan font lainnya sesuai dengan kebutuhan pada perancangan media informasi interaktif tentang program studi di STMIK STIKOM Indonesia.

3. Warna

Sesuai dengan konsep perancangan ini maka penulis menggunakan warna cerah untuk menunjang proses perancangan aplikasi. Penggunaan warna-warna yang cerah diharapkan mampu memberikan daya tarik tersendri bagi pengguna aplikasi tersebut.

4. Audio

Perancangan multimedia interaktif pembelajaran ini memerlukan komponen suara, penulis menggunakan format file .mp3 untuk suara backsound dan format file .wav untuk suara tombol. Dalam perancangan multimedia interaktif akan dilengkapi vocal narasi dan animasi yang bertujuan untuk membantu dalam menjelaskan informasi dalam multimedia interaktif ini. Karena dengan adanya suara, akan mendukung teks yang ada sehingga lebih mudah dan jelas bagi user yang menyimak.

\subsection{Alur Menu}

Pada media yang akan dirancang dan dibangun terdapat 23 halaman, diantaranya halaman pembuka atau intro, halaman menu utama yang berisi halaman teknik informatika, sistem komputer, dan STIKI Indonesia. Halaman teknik informatika berisi 3 halaman yaitu manajemen teknik informatika, desain multimedia, dan komputer akuntansi bisnis. Pada masing-masing halaman manajemen teknik informatika, desain multimedia, dan komputer akuntansi bisnis, memiliki 3 halaman yang sama yaitu gambaran umum, profil lulusan, dan testimoni, namun ke 3 halaman tersebut memiliki konten yang berbeda. Kemudian pada halaman sistem komputer, terdapat 3 halaman yaitu gambaran umum, profil lulusan, dan testimonin. Pada halaman STIKI Indonesia terdapat 3 halaman yaitu foto gedung, foto laboratorium, dan kegiatan UKM. Pada setiap halaman menu terdapat tombol home, tombol ini berfungsi untuk dapat kembali ke menu utama kecuali pada halaman pembuka atau intro. Skema alur menu dapat dilihat pada gambar 3. 


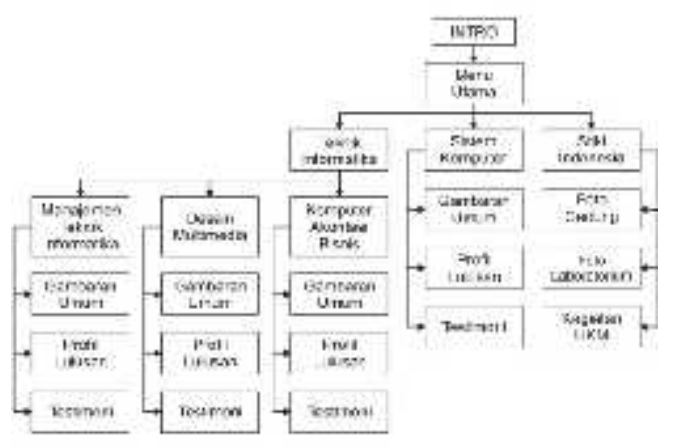

Gambar 3. Alur Menu

\section{HASIL DAN PEMBAHASAN}

Proses membangun media informasi interaktif akan dijelaskan dalam bab ini, mulai dari mendesain aset interaktif berupa aset background dan aset tombol. Dalam interaktif ini terdapat juga aset gambar pada media informasi interaktif yang akan digunakan, aset gambar yang dimaksud berupa foto gedung, foto laboratorium, dan foto kegiatan UKM. Pada bab ini juga akan membahas bagaimana memasukan backsound dan action script yang digunakan sehingga terwujud media pembelajaran dan tahapan akhir adalah pengujian media.

\subsection{Pembuatan Aset Gambar}

Pembuatan aset background dan aset tombol dilakukan melalui software Corel Draw X4 dengan ukuran lembar kerja 1024 x 768 pixels. Dalam merancang media informasi interaktif, maka dalam pembuatan aset menggunakan beberapa tool seperti bezier tool dan shape tool untuk membuat bentuk background dan tombol. Agar warna yang digunakan konsisten maka pewarnaan dalam media informasi interaktif tersebut menggunakan palette. Tampilannya dapat dilihat pada gambar 4dan gambar 5.

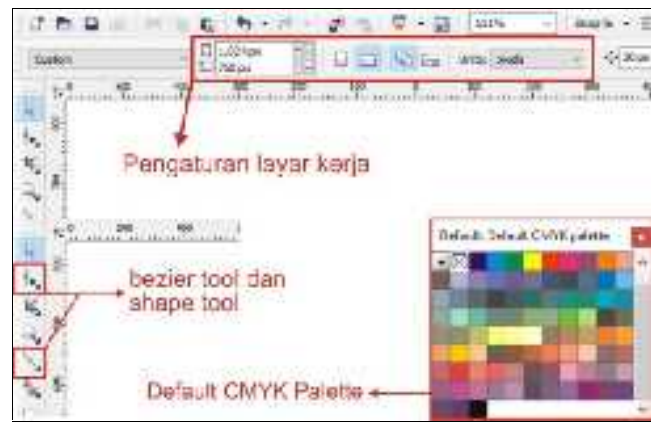

Gambar 4. Tampilan Pengaturan Lembar Kerja Dan Tool Yang Digunakan

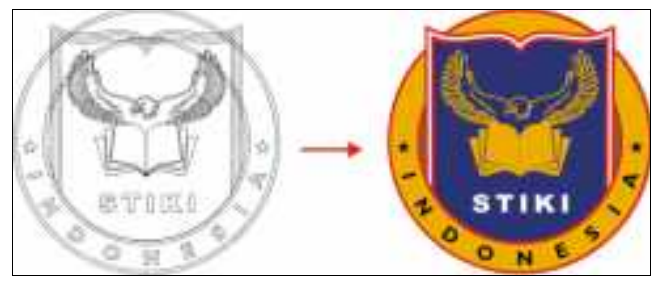

Gambar 5. Proses Pewarnaan Logo Vektor

\subsubsection{Desain Background}

Dalam pembuatan desain background atau latar, tool yang akan digunakan adalah bezier tool dan shape tool untuk membuat bentuk background. Bezier tool berfungsi untuk membentuk gambar kasar dalam sebuah desain yang akan dibuat. Kemudian shape tool berfungsi sebagai penghalus dari gambar kasar yang sudah dibentuk dengan bezier tool sehingga gambar terlihat lebih sempurna. Background yang dibuat sesuai dengan konsep awal yang bertema ceria yang disampaikan dengan banyak warna dan informatif, maka warna yang lebih akan ditonjolkan adalah warna-warna cerah dalam pembuatan background interaktif ini.

Backgroundintro merupakan background yang akan digunakan pada awal saat menjalan media interaktif. Dalam backgroundintro menggunakan warna cerah sehingga sesuai dengan konsep ceria yang disampaikan 
degan banyak warna. Pada bagian backgroundintro akan terdapat kata sambutan selamat datang dimedia informasi interakti program studi STMIK STIKOM indonesia. Backgroundintro dapat dilihat pada gambar 6.

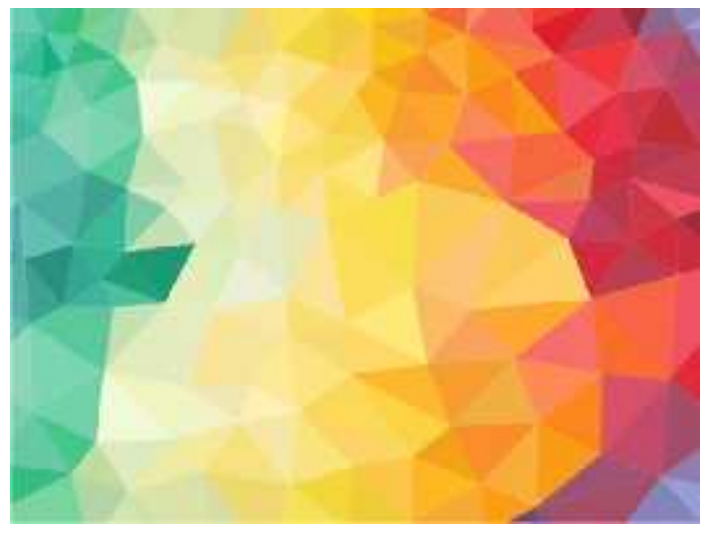

Gambar 6. Desain Background Intro

Background tetap, merupakan background yang akan digunakan pada setiap menu. Warna yang digunakan background tetap menggunakan warna cerah. Tujuan penggunaan background tetap pada setiap menu adalah untuk memeberikan kesan konsistensi terhadap pengguna media interaktif, dengan adanya konsistensi maka akan membantu user lebih mudah memahami cara kerja media interaktif ini. Desain background tetapdapat dilihat pada gambar 7 .

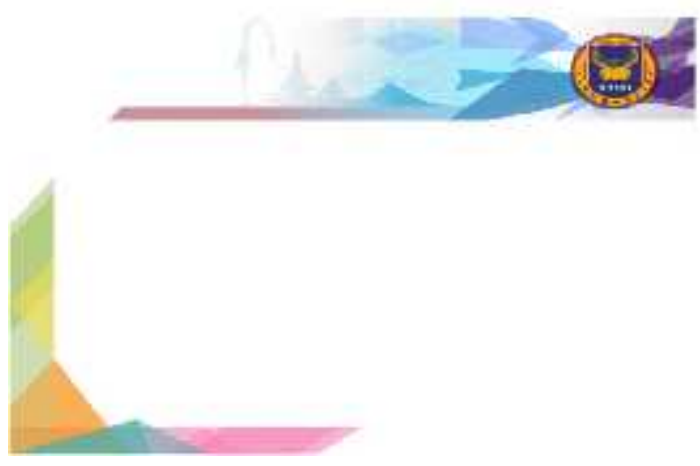

Gambar 7. Desain Background Tetap

\subsubsection{Desain Tombol}

Dalam media informasi interaktif terdapat beberapa tombol untuk memudahkan user dalam menggunakan media interaktif ini. Desain tombol akan menggunakan gambar vector sesuai dengan desain background. Warna tombol yang digunakan adalah warna cerah yang di sesuaikan dengan konsep. Desain tombol dapat dilihat pada gambar 8 .

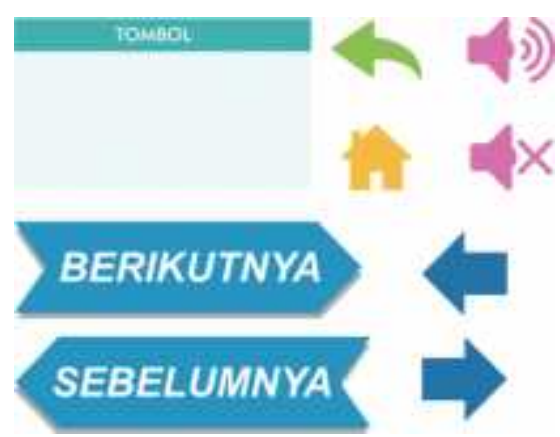

Gambar 8. Desain Tombol

\subsection{Gambar Materi Informasi}

Terdapat beberapa macam gambar bitmap atau foto yang digunakan sebagai pendukung materi informasi dalam merancang media informasi interaktif. Gambar foto akan digunakan pada menu yang terdapat 
materi informasi, sehingga lebih menarik saat membaca materi informasi. Pada tombol tertentu juga akan menggunakan foto untuk mendeskripsikan informasi yang terdapat didalam tombol tersebut. Gambar materi informasi dan gambar tombol dengan foto dapat dilihat pada gambar 9 dan gambar 10.

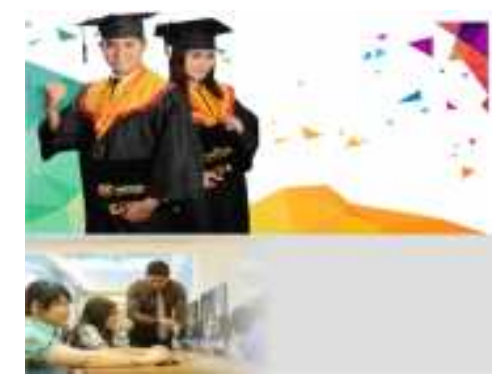

Gambar 9. Gambar Pada Menu Informasi

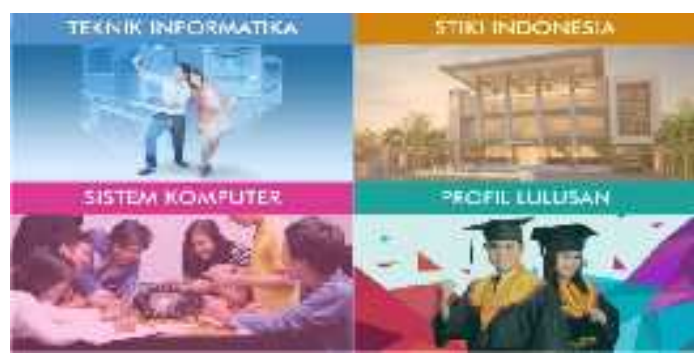

Gambar 10. Gambar Tombol Dengan Foto

\subsection{Animasi}

Pembuatan media informasi interaktif menggunakansoftwareAdobe Flash CS6 dengan Action Script 2.0. Ukuran lembar kerja yang digunakan sama dengan lembar kerja yang digunakan pada pembuatan aset, yaitu $1024 \times 768$ pixelsdengan 30fps. Jumlah perwujudan tampilan menu yang berisi animasi yaitu kurang lebih sebanyak 25 menu. Pengaturan lampiran kerja dan proses animasi dapat dilihat pada gambar 11 dan gambar 12. Untuk tampilan interaktif bisa dilihat pada Gambar 13.

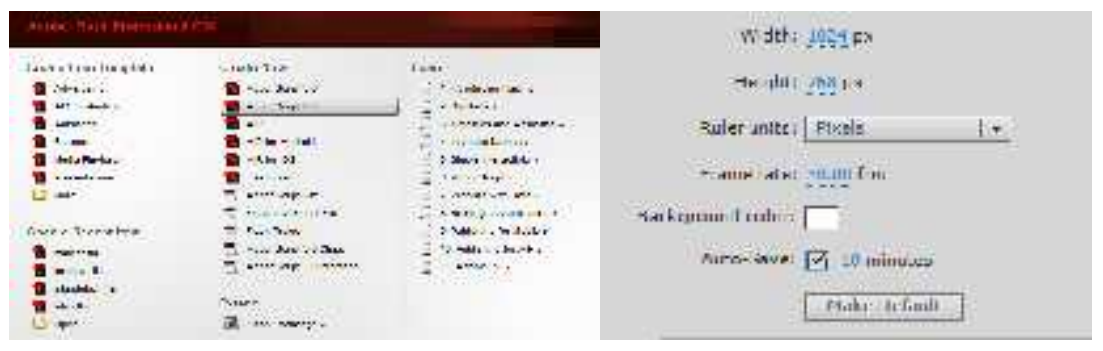

Gambar 11. Tampilan Pengaturan Lembar Kerja

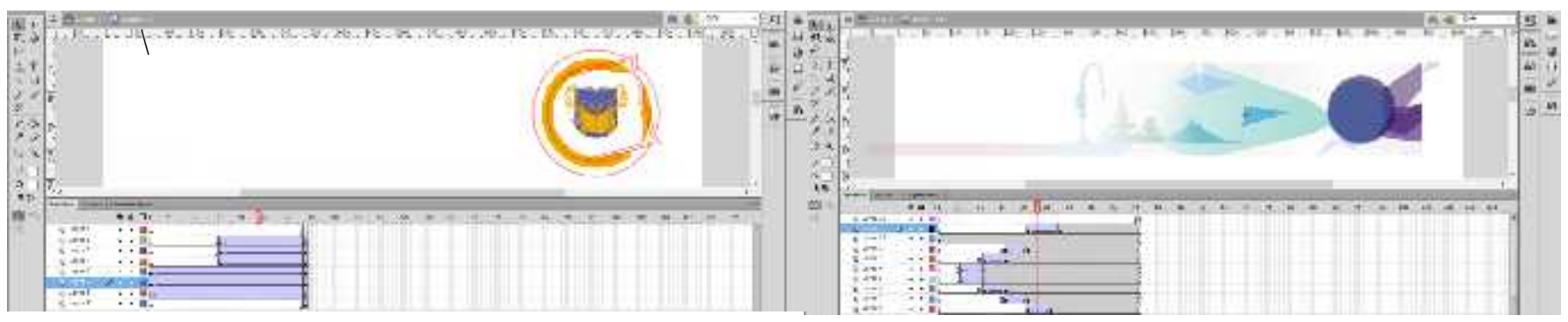

Gambar 12. Proses Pembuatan Animasi 


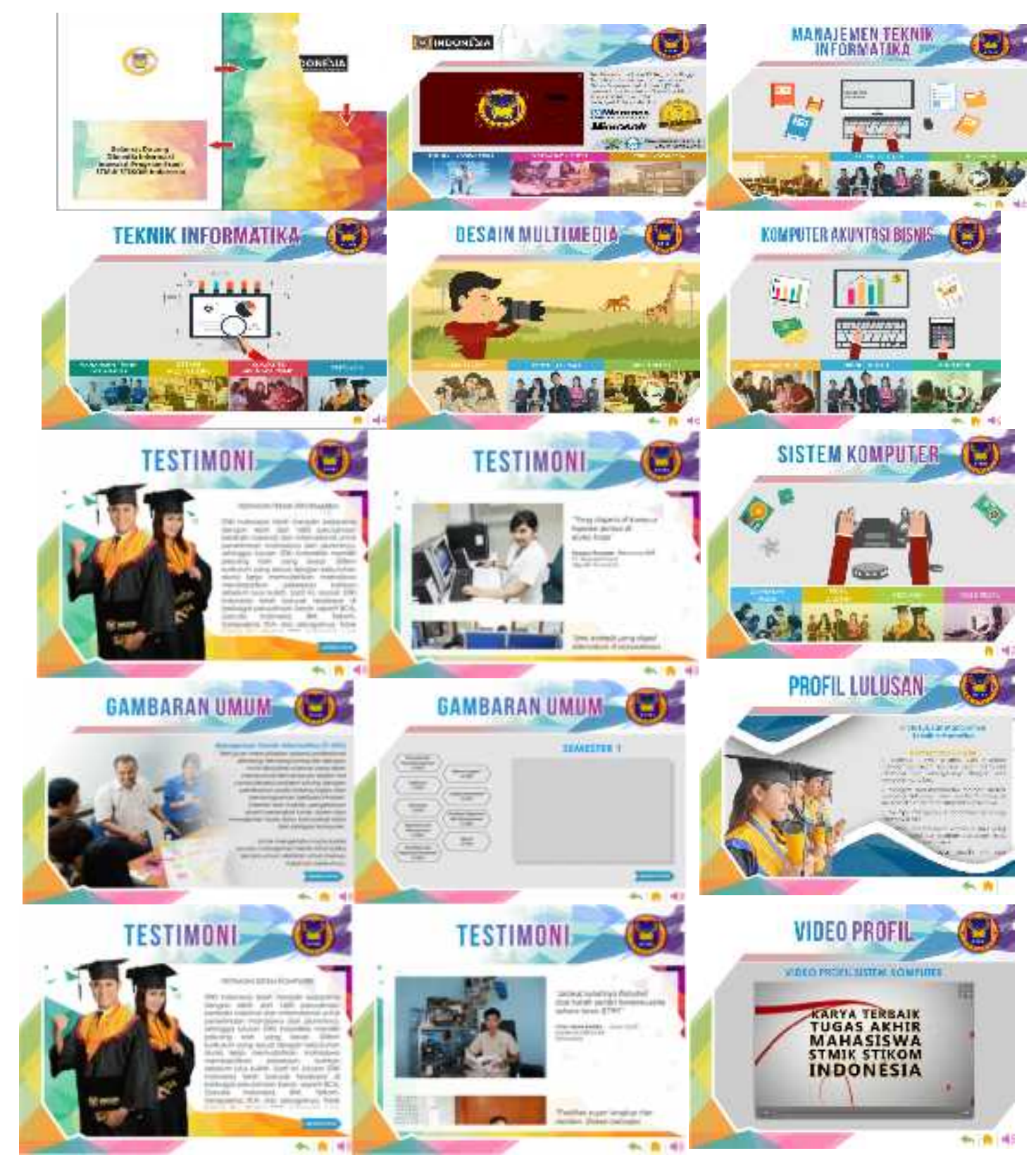

Gambar 13. Tampilan interaktif

\subsection{Analisis Hasil Pengujian}

Setelah media informasi interaktif selesai, tahapan selanjutnya adalah melakukan pengujian untuk mengetahui untuk mengetahui apakah informasi tentang program studi yang disampaikan dalam interaktif multimedia tersebut sudah benar dan tersampaikan dengan baik sehingga layak untuk dipublikasikan. Penguian dilakukan kepada pembantu ketua, kaprodi, ketua lembaga penelitian dan pengabdian masyarakat (LPPM), dan lembaga penjaminan mutu internal (LPMI) STMIK STIKOM Indonesia. Responden berjumlah 10 orang. Pengujian dilakukan dengan memberikan beberapa pernyataan melalui kuesioner. Adapun data yang diperoleh dapat dilihat pada tabel 1. Sebelumnya akan dipaparkan penjelasan dari kategori tabel pada gambar 14. 
Jml : Jumlah responden yang memilih kategori jawaban.

Frek \% : Persentase dari responden yang memilih kategori jawaban. Ditentukan dengan rumus sebagai berikut:

P: Persentase

f: Frekuensi/ Jumlah

$$
\frac{\mathrm{P}=\mathrm{f} \times 100 \%}{\mathrm{~N}}
$$

Poin : Nilai dari Kategori Jawaban

$\begin{array}{ll}\text { Sangat setuju } & : 5 \\ \text { Setuju } & : 4 \\ \text { Netral } & : 3 \\ \text { Tidak Setuju } & : 2 \\ \text { Sangat Tidak Setuju } & : 1\end{array}$

Poin akan dikalikan dengan jumlah responden yang menjawab kategori pertanyaan

Jumlah Poin Kategori adalah jumlah poin keseluruhan pada pernyataan. Ditentuka dengan rumus :

$$
\mathrm{K}=\mathrm{f} / \mathrm{N}
$$
K: Angka Kategori
f: Jumlah Poin Likert
N: Jumlah Sampel

Gambar 14. Penjelasan tentang kategori tabel

Tabel 1. Hasil Pengujian Media Informasi Interaktif Tentang Program Studi

\begin{tabular}{|c|l|l|c|c|c|}
\hline \multirow{2}{*}{ No } & Pernyataan & Kategori Jawaban & Jml & $\begin{array}{c}\text { Frek } \\
\mathbf{\%}\end{array}$ & Poin \\
\hline \multirow{3}{*}{1} & $\begin{array}{l}\text { Informasi tentang kampus } \\
\text { stiki dalam interaktif } \\
\text { multimedia ini sudah } \\
\text { benar dan tersampaikan } \\
\text { dengan baik. }\end{array}$ & Sangat Setuju & 6 & 60 & 30 \\
\cline { 2 - 6 } & Setuju & 4 & 40 & 16 \\
\cline { 2 - 6 } & Netral & 0 & 0 & 0 \\
\cline { 2 - 6 } & Tidak Setuju & 0 & 0 & 0 \\
\cline { 2 - 6 } & Sangat Tidak Setuju & 0 & 0 & 0 \\
\hline Jumlah Poin & \multicolumn{2}{|l|}{} & 46 \\
\hline Jumlah Poin Kategori
\end{tabular}

\begin{tabular}{|c|l|l|c|c|c|}
\hline No & \multicolumn{1}{|c|}{ Pernyataan } & Kategori Jawaban & Jml & $\begin{array}{c}\text { Frek } \\
\%\end{array}$ & Poin \\
\hline \multirow{2}{*}{2} & $\begin{array}{l}\text { Informasi tentang program } \\
\text { studi dan kopetensi } \\
\text { keilmuan dalam interaktif } \\
\text { multimedia ini sudah } \\
\text { benar dan tersampaikan } \\
\text { dengan baik. }\end{array}$ & Sangat Setuju & 6 & 60 & 30 \\
\cline { 2 - 6 } & Setuju & 4 & 40 & 16 \\
\cline { 2 - 6 } & Tetral & 0 & 0 & 0 \\
\cline { 2 - 6 } & Tidak Setuju & 0 & 0 & 0 \\
\hline Jumlah Poin & Sangat Tidak Setuju & 0 & 0 & 0 \\
\hline Jumlah Poin Kategori & & & 46 \\
\hline
\end{tabular}

\begin{tabular}{|c|l|l|c|c|c|}
\hline \multirow{2}{*}{ No } & Pernyataan & Kategori Jawaban & Jml & $\begin{array}{c}\text { Frek } \\
\mathbf{\%}\end{array}$ & Poin \\
\hline \multirow{3}{*}{3} & $\begin{array}{l}\text { Suara narator dalam } \\
\text { interaktif multimedia ini } \\
\text { sudah terdengar dengan } \\
\text { jelas. }\end{array}$ & Sangat Setuju & 4 & 40 & 20 \\
\cline { 2 - 6 } & Setuju & 5 & 50 & 20 \\
\cline { 2 - 6 } & Netral & 0 & 0 & 0 \\
\cline { 2 - 6 } & Tidak Setuju & 1 & 10 & 2 \\
\cline { 2 - 6 } & Sangat Tidak Setuju & 0 & 0 & 0 \\
\hline Jumlah Poin & \multicolumn{2}{|l|}{} & 42 \\
\hline Jumlah Poin Kategori
\end{tabular}




\begin{tabular}{|c|l|l|c|c|c|}
\hline \multirow{2}{*}{ No } & \multicolumn{1}{|c|}{ Pernyataan } & Kategori Jawaban & Jml & $\begin{array}{c}\text { Frek } \\
\mathbf{\%}\end{array}$ & Poin \\
\hline \multirow{3}{*}{4} & \multirow{3}{*}{$\begin{array}{l}\text { Tampilan dalam interaktif } \\
\text { multimedia ini menarik } \\
\text { dan nyaman untuk lihat }\end{array}$} & Sangat Setuju & 4 & 40 & 20 \\
\cline { 3 - 6 } & Setuju & 4 & 40 & 16 \\
\cline { 3 - 6 } & Netral & 2 & 20 & 6 \\
\cline { 2 - 6 } & Tidak Setuju & 0 & 0 & 0 \\
\cline { 2 - 6 } & Sangat Tidak Setuju & 0 & 0 & 0 \\
\hline Jumlah Poin & \multicolumn{2}{|l|}{} & 42 \\
\hline Jumlah Poin Kategori
\end{tabular}

\begin{tabular}{|c|l|l|c|c|c|}
\hline \multirow{2}{*}{ No } & \multicolumn{1}{|c|}{ Pernyataan } & Kategori Jawaban & Jml & $\begin{array}{c}\text { Frek } \\
\boldsymbol{\%}\end{array}$ & Poin \\
\hline \multirow{3}{*}{5} & \multirow{3}{*}{$\begin{array}{l}\text { Interaktif multimedia ini } \\
\text { sudah layak untuk } \\
\text { digunakan }\end{array}$} & Sangat Setuju & 5 & 50 & 25 \\
\cline { 2 - 6 } & Setuju & 4 & 40 & 16 \\
\cline { 2 - 6 } & Netral & 1 & 10 & 3 \\
\cline { 2 - 6 } & Tidak Setuju & 0 & 0 & 0 \\
\cline { 2 - 6 } & Sangat Tidak Setuju & 0 & 0 & 0 \\
\hline Jumlah Poin & \multicolumn{2}{|l|}{} & 44 \\
\hline Jumlah Poin Kategori
\end{tabular}

\begin{tabular}{|r|r|r|r|r|r|}
\hline & $\begin{array}{c}\text { Tidak } \\
\text { Baik }\end{array}$ & $\begin{array}{c}\text { Kurang } \\
\text { Baik }\end{array}$ & $\begin{array}{c}\text { Cukup } \\
\text { Baik }\end{array}$ & Baik & $\begin{array}{c}\text { Sangat } \\
\text { Baik }\end{array}$ \\
\hline 0,5 & 1 & 2 & 3 & 4 & 5 \\
\hline
\end{tabular}

Keterangan :

$\mathrm{y}=$ Jumlah Poin Kategori

\section{Gambar 15. Garis skala kontinum}

Berdasarkan data yang ditujukan pada tabel 1, hasil pengujian interaktif multimedia dari peryataan pertama diketahui bahwa $60 \%$ dari jumlah responden menyatakan sangat setuju jika informasi tentang kampus stiki dalam interaktif multimedia ini sudah benar dan tersampaikan dengan baik, sedangkan $40 \%$ menyatakan setuju. Jumlah poin kategori dari pernyataan tersebut adalah 4.6, berdasarkan garis sekala kontinum pada gambar 15 jumlah poin 4.6 termasuk dalam kategori Sangat Baik.

\section{PENUTUP}

\subsection{Kesimpulan} berikut.

Berdasarkan laporan yang telah dipaparkan sebelumnya, dapat disimpulkan beberapa hal, yaitu sebagai

1. Pembuatan media informasi interaktif ini membutuhkan beberapa proses, yaitu, proses pra-produksi yang meliputi pengumpulan data, analisa data, dan pembuatan alur menu. Proses yang kedua yaitu proses produksi yang meliputi proses pembuatan aset gambar, dan pembuatan multimedia interaktif. Dan proses yang terakhir yaitu proses pasca-produksi yang meliputi penambahan video, animasi, dan export media informasi interaktif ke dalam format .exe.

2. Pengujian media informasi interaktif tentang program studi di STMIK STIKOM Indonesia berbasis desktop ini dilakukan untuk mengetahui kelayakan video dengan mengajukan kuesioner kepada 10 responden internal STMIK STIKOM Indonesia. Setelah dilakukan pengujian selanjutnya penulis menganalisa hasil pengujian dan didapatkan hasil bahwa informasi tentang program studi dan kompetensi keilmuan yang disampaikan melalui multimedia interaktif tersampaikan dengan sangat baik. Sedangkan dari segi tampilan dan audio dari multimedia interaktif ini termasuk dalam kategori sangat baik. Sehingga media informasi interaktif sudah layak untuk di publikasian.

\subsection{Saran}

Pada penulisan tugas akhir ini, masih terdapat banyak kekurangan yang dapat disempurnakan lagi pada pengembangan perancangan media informasi interaktif berikutnya. Agar media informasi interaktif ini menjadi lebih baik lagi, maka adapun saran yang dapat dipergunakan adalah:

1. Perlu ditambahkan petunjuk pemakaian pada setiap menu agar memudahkan dalam menggunakan media informasi interaktif.

2. Diperbanyak dengan menggunakan Action Script 3.0 agar dapat dijalankan menggunakan perangkat mobile. 
3. Untuk peneliti selanjutnya pada saat pengujian diperlukannya ujian evaluasi kepada calon mahasiswa baru, agar mengetahui sejauh mana calon mahasiswa baru mengetahui program studi secara lebih detail setelah adanya media ini.

\section{DAFTAR PUSTAKA}

[1] Al-Firdaus, Iqra'. 2010. Buku Lengkap Tuntunan Menjadi Kameramen Profesional. Yogyakarta: BukuBiru.

[2] Arikunto, Suharsimi. 1985.Prosedur Penelitian. Jakarta: Rieneke Cipta.

[3] Baried, dkk. 2010.Pengantar Teori Filologi.Jakarta: Pusat Pembinaan Dan Pengembangan Bahasa Departemen Pendidikan Dan Kebudayaan.

[4] Baskin, Askurifai. 2003.Membuat Fim Indie Itu Gampang. Bandung: Kanisius.

[5] Effendy, Heru. 2009.Mari Membuat Film : Panduan Menjadi Produser. Yogyakarta: Erlangga.

[6] Hendratman, Hendi. 2012.The Magic Of Adobe Premiere Pro. Yogyakarta: Informatika.

[7] Hendratman, Hendi. 2012.The Magic Of Adobe After Effect. Yogyakarta: Informatika.

[8] Laelasari, Dan Etsa Indra I. 2011.Sinematografi : Panduan Usaha Mandiri. Bandung: Yrama Widya.

[9] Marzuki. 2000.Metodologi Riset. Yogyakarta: BPFE-UII(Bagian Penerbit Fakultas Ekonomi Universitas Islam Indoonesia).

[10] Senn, James A. 1998.Information Technology In Business. Person College Division, page 343.

[11] Sarwono, Jonathan. 2010.Pintar Menulis Karya Ilmiah-Kunci Sukses Dalam Menulis Ilmiah.Yogyakarta: C.V Ando Offset.

[12] Thompson,Dan David Brodwell. 2004.Film Art An Introduction.. New York,McGraw Hill Companies. Inc.

[13] Umbara, Dan Wahyu Wary Pintoko. 2010.How To Become A Cameramen. Yogyakarta: Interprebook.

[14] Utud, Dan Rusman Latief. 2013.Kamus Pintar Broadcasting. Bandung: Yrama Widya.

[15] Wibowo, Fred. 2007.Teknik Produksi Program Televisi. Yogyakarta: Pinus Book Publisher.

[16]Zoebazary, Ilham. 2010.Kamus Istilah Televisi Dan Film. Jakarta: Gramedia Pustaka Utama 